\title{
Analisis preferensi masyarakat terhadap minat membeli produk makanan berlabel halal di Kota Kuala Tungkal Kabupaten Tanjung Jabung Barat
}

\author{
Andre Prianto*;Amri Amir;Paulina Lubis \\ Prodi Ekonomi Pembangunan, Fak. Ekonomi dan Bisnis, Universitas Jambi \\ E-mail korespondensi: andrprynt30@gmail.com
}

\begin{abstract}
The main objectives of this research are to analyze the characteristics of Mini Market consumers, traditional markets, and street vendors and analyze the factors that influence the interest of buying halal labeled food products in Kuala Tungkal Tanjung Jabung Barat District. The data used in this study is the primary data. The result of the research found the characteristics of the interest of the Mini Market consumers, traditional markets, and street vendors products in Kuala Tungkal Tanjung Jabung Barat District based on female gender is 64\%, Islamic religion 72\%, senior high school education $68 \%$, 44\% self-employed, Rp 1.000.000-Rp 2.000.000 as much as 38\% and consumer response does not care about the halal label as much as $28 \%$. the result of research indicates that comprehension, packaging, and hygiene variables influence the interest in buying halal labeled food products in Kuala Tungkal.
\end{abstract}

Keyword: Halal, Consumer, Market.

\begin{abstract}
Abstrak
Penelitian ini bertujuan untuk menganalisis karakteristik konsumen Mini Market, pasar tradisional, dan pedagang kaki lima dan menganalisis faktor-faktor yang mempengaruhi minat membeli produk makanan berlabel halal di Kuala Tungkal Kabupaten Tanjung Jabung Barat. Data yang digunakan dalam penelitian ini adalah data primer. Hasil penelitian menemukan bahwa karakteristik konsumen Mini Market, pasar tradisional, dan pedagang kaki lima di Kota Kuala Kabupaten Tanjung Jabung Barat berdasarkan jenis kelamin perempuan sebesar $64 \%$, agama Islam sebesar $72 \%$, tingkat pendidikan untuk SLTA sebesar $68 \%$, pekerjaan wiraswasta sebanyak 44\%, pendapatan Rp 1.000.000-Rp 2.001 .000 sebanyak 38\% dan respon konsumen tidak perduli label halal sebanyak $28 \%$. Berdasarkan hasil penelitian menunjukkan bahwa semua variabel pemahaman, kemasan, dan kebersihan mempengaruhi minat membeli produk makanan berlabel halal di Kota Kuala Tungkal.
\end{abstract}

Kata kunci: Halal, Konsumen, Pasar

\section{PENDAHULUAN}

Al Qur'an adalah kalam Allah SWT yang diturunkan kepada Nabi Muhammad SAW untuk dijadikan sebagai pedoman dalam kehidupan manusia, baik aqidah, akhlak, ibadah maupun muamalah. oleh karenanya di dalam kandungan Al Qur'an pun terdapat kajian tentang persoalan ekonomi. Seperti dimaklumi, bahwa salah satu persoalan penting dalam kajian ekonomi Islam ialah masalah konsumsi. Konsumsi berperan sebagai pilar dalam kegiatan ekonomi seseorang (individu), perusahaan maupun negara. Konsumsi 
adalah bagian akhir dari kegiatan ekonomi, setelah produksi dan distribusi, karena barang dan jasa yang diproduksi hanya untuk di konsumsi. Konsumsi adalah suatu kegiatan yang bertujuan menggunakan manfaat dari barang dan jasa dalam rangka untuk memenuhi kebutuhan hidup atau konsumsi yaitu tindakan manusia memakai dan menikmati guna barang ataupun jasa untuk memenuhi kebutuhan hidupnya (Winardi, 2009).

Ajaran Islam menjelaskan dalam Al Qur'an dan Hadits memberikan petunjukpetunjuk yang sangat jelas tentang konsumsi, perilaku konsumsi yang sesuai dengan ketentuan Allah dan Rasul-Nya akan menjamin kehidupan manusia yang adil dan sejahtera dunia akhirat (Falah). Menurut Ali (1988), konsumsi merupakan alat dalam memaksimalkan pencapaian falah. Kegiatan mengkonsumsi bukan sekedar untuk menghilangkan lapar ataupun memenuhi kebutuhan fisik, tetapi juga di pertimbangkan mengandung hal-hal yang haram atau tidak. Allah SWT melarang mengkonsumsi, memakan, dan menggunakan yang haram. Larangan mengenai mengkonsumsi, memakan, dan menggunakan hal-hal yang haram tersebut di jelaskan dalam al qur'an Surat Al Baqarah ayat 173 yang berbunyi "sesungguhnya allah mengharamkan bagimu bangkai, darah, daging babi, dan binatang yang (ketika di sembelih) di sebut (nama) selain Allah. Tetapi barang siapa dalam keadaan terpaksa (memakannya) sedangkan dia tidak menginginkannya dan tidak (pula) melampui batas, maka tidak ada dosa baginya".

Sesungguhnya Allah maha pengampun lagi maha penyayang.dalam hadist juga di jelaskan tentang balasan bagi orang yang mengkonsumsi serta menggunakan hal-hal yang haram. Hadist tersebut diriwayatkan dari Abu Bakar ra: "Tidak akan masuk kedalam surga daging yang tumbuh dari sumber yang haram, nerakalah yang layak baginya." (riwayat Imam Ahmad di dalam Musnadnya), manakala riwayat yang lain bermaksud: "Tidak akan masuk surga tubuh badan yang membersar dengan sumber yang haram." (riwayat Al-Khatib al-Tabriziy di dalam Miyskah al-Misbah). Maksud hadist ini adalah tubuh badan atau dagimg yang membesar bersumberkan makananharam maka di akhirat kelak sebagai balasan neraka jahanam tempat baginya sebagai balasan. Orang yang makan makanan haram sama dengan berusaha menghancurkan dirinya, merusak ibadahnya, mempermainkan doanya dan menghancurkan keluarga serta keturunannya.

Ketidakinginan masyarakat muslim untuk mengkonsusmsi produk-produk haram akan meningkatkan kejelian dalam proses pemilihan produk (high involvement). Sehingga akan ada produk yang dipilih untuk di konsumsi dan produk yang tersisih. Dalam Islam umat muslim diwajibkan mengkonsumsi makanan yang halal, karena setiap makanan yang kita konsumsi akan mendarah daging dalam tubuh dan menjadi sumber energi yang penting untuk kehidupan. Rasulallah SAW bersabda: "Tidaklah tumbuh daging dari makanan haram, kecuali neraka lebih utama untuknya”. (HR At Tarmidzi).

Kehalalan sebagai parameter utama dalam proses pemilihan produk. Ketentuan ini membuat keterbatasan pada produk-produk makanan untuk memasuki pasar umat muslim. Memastikan makanan yang di konsumsi halal menjadi tanggung jawab bagi setiap muslim. Untuk mempermudah mengetahui makanan yang di konsumsi halal khususnya makanan dalam kemasan makanan tersebut. Menurut Majelis Ulama Indonesia (MUI) di jaman sekarang ini masyarakat dalam mengkonsumsi produk pangan kurang memperhatikan label halal. Kondisi sebagian besar cenderung bersikap bersikap masa bodoh dalam mengkonsumsi berbagai macam produk yang ada di pasar. Kondisi ini sangat memprihatinkan, mengingat Indonesia adalah negara dengan mayoritas penduduknya memeluk agama Islam, bahkan terbesar di dunia, tapi ternyata belum begitu menganggap penting status kehalalan makanan yang akan di konsumsi.

Label halal yang resmi adalah label halal yang diterbitkan oleh badan resmi pemerintah. Dalam UU No.33 Tahun 2014 pasal 33 ayat 1 tentang jaminan produk halal 
dijelaskan bahwa penetapan kehalalan produk dilakukan oleh MUI dalam sidang Fatwa Halal. Dalam sidang tersebut mengikutsertakan para pakar, unsur kementerian/ lembaga, dan instansi terkait. Sedangkan pemeriksaan atau pengujian produk dilakukan oleh BPJPH (Badan Penyelenggara Jaminan Produk Halal). Jadi label halal yang di pasang di produk tanpa memulai proses pemeriksaan oleh BPJPH dan disahkan oleh MUI bukan merupakan label halal yang resmi. Menurut Tjiptono (1997), label merupakan bagian dari suatu produk yang menyampaikan informasi tentang produk dan penjual.

Label pada produk pangan hal yang sangat penting untuk diperhatikan. Sesuai dengan peraturan pemerintah No. 69 Tahun 1999 Tentang label dan iklan pangan pasal 2 ayat 1 "Bahwa setiap orang yang memproduksi atau memasukkan pangan yang dikemas ke dalam wilayah Indonesia untuk diperdagangkan wajib mencatumkan label pada produk pangan di dalam dan atau di kemasan pangan". Label merupakan alat penyampai informasi mengenai nama produk, label juga memberikan informasi daftar bahan yang terkandung dalam produk, berat bersih, daya tahan, nilai ataupun kegunaan produk serta keterangan tentang halal.

Pencantuman tulisan "halal" diatur oleh keputusan bersama Menteri Kesehatan dan Menteri Agama No. 427/MENKES/SKB/VIII/1985. Makanan halal adalah semua jenis makanan yang tidak mengandung unsur atau bahan yang dilarang/ haram atau yang diolah menurut hukum-hukum Islam. Produk yang mencantumkan tulisan 'halal' pada label/ penandaan makanan produknya bertanggung jawab terhadap halalnya makanan tersebut bagi pemeluk agama islam. Masih banyak produk bersertifikat halal palsu beredar di mayarakat.

Dari seluruh produk bersertifikat halal palsu yang beredar di Indonesia baru $59,1 \%$ produk yang berlabel halal MUI yang beredar di masyarakat. Masyarakat seharusnya lebih hati-hati dalam mengenali label halal yang ada dalam kemasan. Seperti yang telah dihimbau oleh Direktur LPPOM-MUI Lukmanul Hakim bahwa saat ini memang banyak produk dengan label halal palsu. Jumlah produk yang berlabel halal palsu angkanya cukup tinggi yaitu 40 hingga 50 persen dan ini adalah produk-produk yang telah mendapat registrasi sehat dan baik dari Badan Pengawas Obat dan Makanan (BPOM).

Realita masyarakat Indonesia sekarang masih banyak kaum muslim yang hampir tidak peduli, menganggap enteng, bahkan cenderung meremehkan kehalalan makanan yang dikonsumsinya. Kondisi ini disebabkan terutama karena kurangnya pengetahuan dan pemahaman yang menyebabkan kurangnya kesadaran dan ketidakpedulian dari sebagian besar masyarakat Muslim Indonesia. Salah satu faktor penyebabnya adalah kurangnya pemahaman akan hukum dan peraturan. Contoh yang paling jelas adalah masalah label halal. Banyak diantara kita yang menganggap bahwa restoran atau produk yang mencantumkan label halal sudah pasti halal. Padahal realitanya banyak label halal adalah 'self claim' atau pernyataan sepihak tanpa adanya pengujian dari badan yang berwenang. Jika masyarakat paham label yang resmi dan yang bukan, maka mereka akan terhindar dari makanan haram atau subhat.

Kabupaten Tanjung Jabung Barat sebagai daerah yang memiliki potensi ekonomi yang tinggi, serta sebagai daerah perdagangan sudah pasti akan bersaing ketat pada pemasaran produk-produk pangan yang dihasilkan ditambah lagi sudah maraknya produk makanan impor bersetifikasi halal beredar di kabupaten ini khususnya di Kota Kuala Tungkal. Kabupaten Tanjung Jabung Barat merupakan kabupaten dengan penduduk yang agamis dan memiliki mayoritas penduduk adalah beragama Islam dengan jumlah penduduk muslim sebanyak 225.235 orang (Tabel 1). Jadi produk halal dapat berkembang pesat di kabupaten ini. 
Tabel 1. Jumlah penduduk menurut agama di Kabupaten Tanjung Jabung Barat

\begin{tabular}{|c|c|c|}
\hline Penduduk menurut agama & Jumlah (orang) & Persentase ( \% ) \\
\hline a. Budha & 16.691 & 5,84 \\
\hline b. Hindu & 2.202 & 0,77 \\
\hline c. Islam & 225.235 & 78,83 \\
\hline d. Katolik & 12.630 & 4,42 \\
\hline e. Kristen & 22.448 & 7,86 \\
\hline Kepercayaan (Konghucu,dll) & 6.525 & 2,28 \\
\hline Jumlah & 285.731 & 100 \\
\hline
\end{tabular}

Sumber: Data diolah, 2018

Populasi penduduk Kabupaten Tanjung Jabung barat dengan pertumbuhan ratarata mencapai $1,17 \%$. Total penduduk sebanyak 285.731 jiwa dengan mayoriyas penduduk penganut agama Islam hingga mencapai 225.235 jiwa. Menegaskan bahwa Kabupaten Tanjung Jabung Barat sangat berpotensi dalam pengembangan usaha perdagangan sektor makanan dan kebutuhan rumah tangga. Penerapan label halal pada produk-produk makanan sangat menunjang kelanjutan usaha perdagangan produk makanan di mini market yang tersebar di wilayah Kabupaten Tanjung Jabung Barat. Mini market memberi kontribusi peredaran produk makanan yang berlabel halal yang tercantum dikemasan produk makanan tersebut.

Menurut Syahruddin (2014) dengan judul penelitian "Potensi Kemajuan Umat melalui Produk Halal”. Survey membuktikan bahwa 98,3\% perusahaan puas terhadap kinerja LPPOM MUI yang dapat membawa dampak positif kepada produsen dan konsumen. Terjadinya peningkatan produksi pada penjualan produk makanan halal.

Menurut Budi (2013) dengan judul penelitian "Penaruh Label Halal terhadap Keputusan Membeli" menyatakan bahwa label halal mempunyai hubungan yang signifikan terhadap keputusan ditunjukkan dengan nilai sebesar 0,666> $r$ tabel $(0,207)$. Hal ini membuktikan bahwa keberadaan label halal (peneliti ini meneliti produk komestik Wardah) memberikan nilai positif yang memberikan peluang besar dalam mempengaruhi keputusan membeli konsumen.

Menurut Kurniadi (2011) dengan judul penelitian "Studi Komparatif Perilaku Konsumen Presprektif Islam dan Konvensional Analisis Kasus: Apresiasi Konsumen terhadap Produk Halal-Haram dan Implikasinya" menyatakan dalam penelitiannya bahwa potensi produk halal dunia diperkirakan US\$2,1 Triliun per tahun, sedangkan konsumsi makanan halal pada Tahun 2011 diperkirakan melebihi rata-rata pertahun yang mencapai US\$ 666,7 juta. Ini menandakan adanya peningkatan yang signifikan terhadap produksi dan minat terhadap produk halal.

\section{METODE}

Metode penelitian adalah ilmu pengetahuan tentang berbagai cara atau metode atau tehnik yang dipergunakan dalam melaksanakan suatu penelitian ilmiah, Amir, Yulmardi dan Junaidi (2009). Metode penelitian yang digunakan dalam penelitian ini menggunakan data primer dan sekunder. Data yang digunakan dalam penelitian ini terdiri dari dua jenis data yaitu jenis data primer dan data sekunder.

a. Data primer.

Data primer adalah suatu data-data yang diambil langsung oleh sumbernya, tanpa ada perantara sumber yang dimaksud dapat berupa benda, situasi, atau manusia. Adapun 
data primer yang di peroleh melalui observasi langsung dari hasil angket dengan di sebarkannya pada responden konsumen Mini market, pasar tradisional, dan kaki lima di Kabupaten Tanjung Jabung Barat.

b. Data sekunder

Data sekunder berupa data yang diperoleh dari instansi pihak terkait yang merupakan hasil olahan dari pihak tersebut. Data yang dibutuhkan dalam penelitian ini adalah jumlah Mini Market, pasar tradisional, dan kaki lima yang ada di Kabupaten Tanjung Jabung Barat, Dinas Perindustrian dan Perdagangan, Struktur organisasi, serta data-data hasil penelitian sebelumnya.

Metode analisis data yang digunakan adalah deskriftif kuantitatif. Untuk menjawab pertanyaan pertama maka digunakan analisis deskriftif kualitatif yang merupakan analisis yang digunakan. Deskriftif gambaran mengenai pengaruh pemahaman, kemasan, dan kualitas rasa terhadap minat membeli produk makanan berlabel halal di Mini market, pasar tradisional, dan pedagang kaki lima di Kabupaten Tanjung Jabung Barat. Untuk menguji pertanyaan yang kedua digunakan regresi linier berganda dengan rumus sebagai berikut (Firdaus, 2011) :

Dimana :

$$
Y=\beta 0+\beta 1 X 1+\beta 2 X 2+\beta 3 X 3+\varepsilon
$$

$\begin{array}{ll}\mathrm{Y} & =\text { Minat Membeli } \\ \beta 0 & =\text { Konstanta } \\ \beta 1 & =\text { Koefisien Regresi } \\ \mathrm{X} 1 & =\text { Pemahaman } \\ \mathrm{X} 2 & =\text { Kemasan } \\ \mathrm{X} 3 & =\text { Kebersihan } \\ \mathrm{E} & =\text { Error term }\end{array}$

\section{HASIL DAN PEMBAHASAN}

\section{Karakteristik responden berdasarkan jenis kelamin}

Karakteristik responden berdasarkan jenis kelamin terhadap konsumen Mini Market, pasar tradisional, dan pedagang kaki lima di Kota Kuala Tungkal Kabupaten Tanjung Jabung Barat dapat di lihat sebagai berikut :

Tabel 2. Karakteristik responden berdasarkan jenis kelamin

\begin{tabular}{clcc}
\hline No & Jenis kelamin & Jumlah responden & Persentase (\%) \\
\hline 1 & Laki-laki & 36 & 36 \\
2 & Perempuan & 64 & 64 \\
\hline & Total & $\mathbf{1 0 0}$ & $\mathbf{1 0 0}$ \\
\hline
\end{tabular}

Sumber : Data diolah, 2018

Berdasarkan Tabel 2. menjelaskan bahwa dari 100 responden konsumen Mini market, pasar tradisional, dan pedagang kaki lima di Kota Kuala Tungkal Kabupaten Tanjung Jabung Barat dengan jenis kelamin laki-laki menunjukkan jumlah sebanyak 36 orang atau $36 \%$, sedangkan yang jenis kelamin perempuan sebanyak 64 orang atau $64 \%$. Hal ini menunjukkan bahwa sebagian besar responden dalam penelitian ini adalah perempuan. 


\section{Karakteristik responden berdasarkan agama}

Karakteristik responden berdasarkan agama terhadap konsumen Mini market, pasar tradisional, dan pedagang kaki lima di Kota Kuala Tungkal Kabupaten Tanjung Jabung Barat dapat di lihat sebagai berikut :

Tabel 3. Karakteristik responden berdasarkan agama

\begin{tabular}{|c|c|c|c|}
\hline No & Agama & Jumlah responden & Persentase (\%) \\
\hline 1 & Islam & 72 & 72 \\
\hline 2 & Kristen & 10 & 10 \\
\hline 3 & Katolik & 4 & 4 \\
\hline 4 & Hindu & 0 & - \\
\hline 5 & Budha & 0 & - \\
\hline 6 & Kong hu chu & 14 & 14 \\
\hline & Total & 100 & 100 \\
\hline
\end{tabular}

Sumber: Data diolah, 2018

Berdasarkan Tabel 3. menjelaskan bahwa dari 100 responden konsumen mini market, pasar tradisional, dan pedagang kaki lima di Kota Kuala Tungkal Kabupaten Tanjung Jabung Barat dengan agama Islam menunjukkan jumlah sebanyak 72 orang atau $72 \%$, untuk responden yang beragama Kristen sebanyak 10 orang atau $10 \%$, untuk responden yang beragama Katolik sebanyak 4 orang atau $4 \%$, untuk responden yang beragama Kong hu chu sebanyak 14 orang atau 14\%, sedangkan yang beragama Hindu dan Budha tidak ada yang menjadi responden. Hal ini menunjukkan bahwa sebagian besar responden dalam penelitian ini adalah beragama Islam.

\section{Karakteristik responden berdasarkan tingkat pendidikan}

Karakteristik respon berdasarkan tingkat pendidikan terhadap konsumen mini market, pasar tradisional, dan pedagang kaki lima di Kota Kuala Tungkal Kabupaten Tanjung Jabung Barat dapat di lihat sebagai berikut :

Tabel 4. Karakteristik responden berdasarkan tingkat pendidikan

\begin{tabular}{clcc}
\hline No & Tingkat Pendidikan & Jumlah responden & Persentase (\%) \\
\hline 1 & SD & 8 & 8 \\
2 & SLTP & 12 & 12 \\
3 & SLTA & 68 & 68 \\
4 & D1 & 0 & - \\
5 & D3 & 0 & - \\
6 & S1 & 8 & 8 \\
7 & S2 & 4 & 4 \\
\hline \multicolumn{2}{r}{ Total }
\end{tabular}

Sumber : Data diolah, 2018

Berdasarkan Tabel 4. menjelaskan bahwa dari 100 responden konsumen mini market, pasar tradisional, dan pedagang kaki lima di Kota Kuala Tungkal Kabupaten 
Tanjung Jabung Barat dengan tingkat pendidikan SD menunjukkan jumlah sebanyak 8 orang atau $8 \%$, SLTP sebanyak 12 orang atau $12 \%$, SLTA sebanyak 68 orang atau $68 \%$, dan tingkat perguruan tinggi seperti D1 dan D3 tidak ada yang menjadi responden, sedangkan S1 sebanyak 8 orang atau $8 \%$ dan S2 sebanyak 4 orang atau $4 \%$. Hal ini menunjukkan bahwa sebagian besar responden dalam penelitian ini adalah dari tingkat pendidikan untuk SLTA.

\section{Karakteristik responden berdasarkan pekerjaan}

Karakteristik responden berdasarkan pekerjaan terhadap konsumen mini market, pasar tradisional, dan pedagang kaki lima di Kota Kuala Tungkal Kabupaten Tanjung Jabung Barat dapat di lihat sebagai berikut :

Tabel 5. Karakteristik responden berdasarkan pekerjaan

\begin{tabular}{clcc}
\hline No & Pekerjaan & Jumlah responden & Persentase (\%) \\
\hline 1 & Petani & 18 & 18 \\
2 & Nelayan & 16 & 16 \\
3 & PNS & 16 & 16 \\
4 & Wiraswasta & 44 & 44 \\
\hline & Total & $\mathbf{1 0 0}$ & $\mathbf{1 0 0}$
\end{tabular}

Sumber : Data diolah, 2018

Berdasarkan Tabel 5. menjelaskan bahwa dari 100 responden konsumen mini market, pasar tradisional, dan pedagang kaki lima di Kota Kuala Tungkal Kabupaten Tanjung Jabung Barat dengan pekerjaan sebagai petani menunjukkan jumlah sebanyak 18 orang atau $18 \%$, pekerjaan sebagai nelayan menunjukkan jumlah sebanyak 16 orang atau 16\%, dan pekerjaan sebagai PNS menunjukkan jumlah sebanyak 16 orang atau 16\%, sedangkan pekerjaan sebagai wiraswasta menunjukkan jumlah sebanyak 44 orang atau 44\%. Hal ini menunjukkan bahwa sebagian besar responden dalam penelitian ini adalah dari pekerjaan sebagai wiraswasta.

\section{Karakteristik responden berdasarkan pendapatan}

Karakteristik responden berdasarkan pendapatan terhadap konsumen mini market, pasar tradisional, dan pedagang kaki lima di Kota Kuala Tungkal Kabupaten Tanjung Jabung Barat dapat di lihat sebagai berikut :

Tabel 6. Karakteristik responden berdasarkan pendapatan

\begin{tabular}{cccc}
\hline No & Pendapatan & Jumlah Responden & Persentase (\%) \\
\hline 1 & $\leq \operatorname{Rp~1.000.000~}$ & 14 & 14 \\
2 & Rp 1.001.000-Rp 2.000.000 & 38 & 38 \\
3 & Rp 2.001.000-Rp 3.000.000 & 28 & 28 \\
4 & $\geq$ Rp 3.001.000 & 20 & 20 \\
\hline & Total & $\mathbf{1 0 0}$ & $\mathbf{1 0 0}$ \\
\hline
\end{tabular}

Sumber : Data diolah, 2018

Berdasarkan Tabel 6. menjelaskan bahwa dari 100 responden konsumen mini market, pasar tradisional, dan pedagang kaki lima di Kota Kuala Tungkal Kabupaten Tanjung Jabung Barat dengan pendapatan $\leq$ Rp 1.000.000 menunjukkan jumlah sebanyak 14 orang atau 14\%, pendapatan Rp 1.001.000- Rp 2.000.000 menunjukkan jumlah 
sebanyak 38 orang atau 38\%, dan pendapatan Rp 2.001.000- Rp 3.000.000 menunjukkan jumlah sebanyak 28 orang atau $28 \%$. Sedangkan pendapatan $\geq R p 3.001 .000$ menunjukkan jumlah sebanyak 20 orang atau $20 \%$. Hal ini menunjukkan bahwa sebagian besar responden dalam penelitian ini adalah dari pendapatan Rp 1.001.000- Rp 2.000.000.

\section{Karakteristik responden berdasarkan respon konsumen}

Karakteristik responden berdasarkan respon konsumen mini market, pasar tradisional, dan pedagang kaki lima di Kota Kuala Tungkal Kabupaten Tanjung Jabung Barat dapat di lihat sebagai berikut :

Tabel 7. Karakteristik responden berdasarkan respon konsumen

\begin{tabular}{clcc}
\hline No & Respon konsumen & Jumlah responden & Persentase (\%) \\
\hline 1 & Sangat penting label halal & 22 & 22 \\
2 & Memilih label halal & 26 & 26 \\
3 & Tidak peduli label halal & 28 & 28 \\
4 & Tidak perhatian label halal & 24 & 24 \\
\hline \multicolumn{2}{c}{ Total } & $\mathbf{1 0 0}$ & $\mathbf{1 0 0}$
\end{tabular}

Sumber : Data diolah, 2018

Berdasarkan Tabel 7. menjelaskan bahwa dari 100 responden konsumen Mini market, pasar tradisional, dan pedagang kaki lima di Kota Kuala Tungkal Kabupaten Tanjung Jabung Barat dengan respon konsumen menilai sangat penting label halal menunjukkan jumlah sebanyak 22 orang atau $22 \%$, respon konsumen melilih label halal menunjukkan jumlah sebanyak 26 orang atau $26 \%$, respon konsumen tidak peduli label halal menunjukkan jumlah sebanyak 28 orang atau $28 \%$, dan respon konsumen tidak perhatian label halal menunjukkan jumlah sebanyak 24 orang atau $24 \%$. Hal ini menunjukkan bahwa sebagian besar responden dalam penelitian ini menilai tidak peduli label halal.

Faktor-faktor yang mempengaruhi minat masyarakat membeli produk makanan berlabel halal

Penelitian ini bertujuan untuk mengetahui pengaruh dari minat masyarakat membeli produk makanan berlabel halal sebagai variabel dependen, sedangkan faktorfaktor yang mempengaruhi diantaranya pemahaman, kemasan, dan kebersihan sebagai variabel independen. Hasil pengolahan regresi linier berganda dengan Eviews versi 8.0 bertujuan untuk menentukan pengaruh pemahaman, kemasan, dan kebersihan terhadap respon konsumen mini market, pasar tradisional, dan pedagang kaki lima di Kota Kuala Tungkal Kabupaten Tanjung Jabung Barat, sesuai tabel berikut ini :

Tabel 8. Hasil regresi linier berganda

\begin{tabular}{crrrr}
\hline Variable & Coefficient & Std. Error & \multicolumn{1}{c}{ t-Statistic } & \multicolumn{1}{c}{ Prob. } \\
\hline C & 15.74890 & 3.178185 & 4.955311 & 0.0022 \\
PM & 0.048332 & 0.102078 & 1.473478 & 0.0636 \\
KM & 0.216770 & 0.983890 & 2.203191 & 0.0300 \\
KB & 0.096064 & 0.100391 & 1.956897 & 0.0341 \\
R-squared & 0.955050 & F-statistic & 2.026257 \\
& & Prob(F-statistic) & 0.115343 \\
\hline
\end{tabular}

Sumber : Data diolah, 2018

$\mathrm{MN}=f(\mathrm{MN}, \mathrm{KM}, \mathrm{KB})$ 


$$
\mathrm{MN}=\beta_{0}+\beta_{1} \mathrm{PM}+\beta_{2} \mathrm{KM}+\beta_{3} \mathrm{~KB}+\varepsilon
$$

Hasil estimasi yang diperoleh dari koefisien regresi untuk variabel pemahaman (PM) sebesar 0,04833, Artinya jika pemahaman ditingkatkan sebesar satu satuan, maka minat membeli produk makanan belabel halal juga akan mengalami peningkatan sebesar 0,04833. Koefisien kemasan (KM) sebesar 0,21677, Artinya jika kemasan ditingkatkan sebesar satu satuan, maka minat membeli produk makanan belabel halal juga akan mengalami peningkatan sebesar 0,21677. Dan koefisien kebersihan (KB) sebesar 0,09550, Artinya jika kebersihan ditingkatkan sebesar satu satuan, maka minat membeli produk makanan belabel halal juga akan mengalami peningkatan sebesar 0,09550. Maka dapat disimpulkan bahwa variabel pemahaman, kemasan dan kebersihan berpengaruh posistif dan signifikan terhadap minat membeli produk makanan belabel halal di Kota Kuala Tungkal Kabupaten Tanjung Jabung Barat.

\section{KESIMPULAN DAN SARAN}

\section{Kesimpulan}

Berdasarkan karakteristik reponden konsumen mini market, pasar tradisional, dan pedagang kaki lima di Kota Kuala Tungkal Kabupaten Tanjung Jabung Barat terdapat perbedaan yang dapat dilihat dari kelompok responden berdasarkan jenis kelamin, agama, tingkat pendidikan, pekerjaan, pendapatan dan respon konsumen.

Berdasarkan hasil analisis regresi linier berganda variabel pemahaman, kemasan, dan kebersihan yang mempengaruhi minat membeli produk makanan belabel halal di Kota Kuala Tungkal Kabupaten Tanjung Jabung Barat yaitu dengan koefisien masingmasing variabel mempunyai nilai positif dan probabilitasnnya di bawah $10 \%$ yang berarti berpengaruh positif dan signifikan. Maka dapat disimpulkan bahwa variabel pemahaman, kemasan dan kebersihan berpengaruh posistif dan signifikan terhadap minat membeli produk makanan belabel halal di Kota Kuala Tungkal Kabupaten Tanjung Jabung Barat.

\section{Saran}

Pengaruh minat membeli produk makanan belabel halal di Kota Kuala Tungkal Kabupaten Tanjung Jabung Barat sangat positif dan signifikan, sehingga disarankan untuk masyarakat khususnya konsumen lebih berperan aktif mengenali produk makanan.

Perlunya penerangan kepada masyarakat dan instansi-instansi yang berkompeten akan manfaatnya produk makanan berlabel halal secara promosi, baik melalui media cetak maupun media elektronik dengan kontinu. Sehingga sebagai pihak konsumen nantinya akan merasakan hasil manfaat dari mengkonsumsi produk makanan berlabel halal.

\section{DAFTAR PUSTAKA}

A Amir . (2016). pola dan prilaku konsumsi masyarakat muslim di provinsi jambi (telaah berdasarkan tingkat pendapatan dan keimanan), Jurnal Perspektif Pembiayaan dan Pembangunan Daerah 4 (2), 73-88

Ali,M. D.(1988). Sistem ekonomi islam zakat dan wakaf. UI Press: Jakarta.

Amir,Yulmardi dan Junaidi.(2009).Metodologi penelitian ekonomi dan penerapannya.

IPB Press: Bogor. 
Budi,U.W.(2013).Pengaruh Label Halal Terhadap Keputusan Membeli.Skripsi Fakultas Ilmu Sosial dan Humaniora, Universitas Islam Negeri Sunan

Firdaus,M.(2011).Ekonometrika: suatu pendekatan aplikatif. PT Bumi Aksara: Jakarta. Kalijaga.

Kurniadi,E.(2011).Penelitian komperatif, (http//www.ie-greensolution.blogs pot.com.) diunduh 8 Februari 2016.

LE Fitri. (2012). Pengaruh kepercayaan, kepuasan pelanggan dan komitmen hubungan terhadap ekuitas merek dan Citra Bank Syariah XYZ Di Kota Jambi, Jurnal Manajemen Terapan dan Keuangan 1 (3)

Peraturan Pemerintah No. 69 Tahun 1999 Tentang label dan Iklan Pangan Pasal 2 Ayat 1 Syahruddin.(2014), Potensi kemajuan umat melalui produk makanan label halal, http//majalahgontor.net. diunduh 6 Januari 2017.

Tjiptono,F.(2010).Strategi pemasaran. Andy Ofset: Yogyakarta.

Undang-Undansg No.33 Tahun 2014 Pasal 33 Ayat 1 Tentang Jaminan Produk Halal

Winardi.(2009). Pengantar ilmu ekonomi, Tersito: Bandung. 